\title{
Can Ecosystem Services Make Conservation Normal and Commonplace?
}

\author{
Author(s): Kai M. A. Chan, Paige Olmsted, Nathan Bennett, Sarah C. Klain, Elizabeth A. Williams \\ Venue: A chapter in Conservation for the Anthropocene Ocean: Interdisciplinary science in support of nature \\ and people. Phillip S. Levin and Melissa R. Poe (eds).
}

\begin{abstract}
Without widespread and immediate changes in human values and activities, massive tracts of natural habitat will be degraded to the detriment of those ecosystems, ecosystem services, and many threatened taxa-in the oceans and elsewhere. Despite this, the conservation movement has yet to devote much attention to the intentional project of widespread norm change. By one logic, the ecosystem services concept offers a means of integrating meaningful conservation into decision-making by diverse government and corporate actors, potentially normalizing conservation. But normalizing conservation would require not only the uptake of ecosystem-services concepts but also widespread changes in conservation practice and stewardship values-on a scale that far exceeds what we have witnessed to date. The concept of ecosystem services has potential for assisting such a societal transformation because it effectively puts a human face on environmental change, thereby enabling the extension of responsibility and morality into environmental arenas at all scales. Furthermore, cultural ecosystem services merit particular attention because of their contribution to the formation of attachments to particular places and to identities rooted in nature and conservation, which presents an opportunity to consolidate and shape deep motivations for lasting conservation. Realizing these two opportunities in a way that is both appropriate and effective, however, will require several important innovations and new institutions, which we propose here. One key step is to enlist a broad base of consumers and corporations in the funding of actions to mitigate the environmental impacts associated with their participation in global supply chains, via funding vehicles that are conspicuous, easy, enjoyable, and not too expensive. We describe a new initiative called CoSphere that strives to create such structures. With consolidated effort and explicit attention, conservation can become normalized-to the benefit of current people, future generations, and life on Earth.
\end{abstract}

\section{Conservation as Normal and Commonplace}

What would constitute success for the conservation movement? Meeting the Convention on Biological Diversity Aichi targets? That is, protecting 17\% of all terrestrial and inland water areas, and 10\% of coastal and marine areas by 2020 ? One might argue that such targets, despite their apparent specificity, would constitute success only given many caveats and conditions (e.g., that the protected areas are representative sites connected meaningfully in networks, that they are not already too degraded and are strongly protected from ongoing stressors). Perhaps such targets are neither necessary nor sufficient for conservation success.

If, on the other hand, protecting biodiversity were both normal and commonplace (broadly), many conservationists might agree that conservation success was virtually assured. In this chapter, we argue that achieving normality - that is, widespread practice with some kind of moral tinge, even if implicit-is a necessary criterion for success. Currently, economic activity is prioritized as somehow more essential 
to human well-being than the ecosystems on which they rely, artificially separating economic activity and human well-being from the natural environment (Levin 1996; Rees 1998; Daly 2005). As long as protecting biodiversity is seen as a luxury or elitist endeavor, and most economic activity can proceed apace without actively accounting for and mitigating impacts on biodiversity, ecosystems will continue to be buffeted by massive, unprecedented and growing pressures. The cumulative impacts of such pressures can only be large. We are, after all, in the Anthropocene (Steffen et al. 2007; Dirzo et al. 20|4).

Conservation must account for and enlist the billions of people who regularly consume products made from raw materials that are often extracted from ecosystems and the Earth's crust thousands of kilometers away, then processed into components and assembled in other distant locations. In the context of this global economy, we see conservation as no less than the internalization of externalities throughout global supply chains. To succeed in the Anthropocene, conservation must go far beyond protected areas and endangered species in places we know; it will require the proactive mitigation of impacts on biodiversity and ecosystem processes in all manner of economic activity, anywhere (Ehrlich \& Pringle 2008). By our view, it must also attend to the human consequences of these ecological effects, and to issues of justice via the production and distribution of goods and ills, and the processes involved (Schlosberg 2004; Chan \& Satterfield 2013). Put this way, success seems a distant possibility.

Normalizing this kind of conservation is a bold aspiration, and not yet a goal that unites the conservation movement. While conservationists might generally agree with such an objective, most are preoccupied with protecting particular cherished species and places from the negative consequences of economic activity. We must fight the fires. But the global aggregation of such local 'fire-fighting' does not equate to charting an economic transformation that prevents such impacts, nor does it create a society that takes responsibility for them. Fire-fighting is not fire-proofing.

In this article, we consider what conservation fire-proofing or normalization might entail. We first consider the rise of ecosystem services as a field, and the hope that it might make conservation commonplace, amidst concerns that embracing ecosystem services might undermine true conservation. We then consider what it might mean to normalize conservation, the extent to which this lofty goal is even an active project within the conservation movement, and the role of ecosystem services in these efforts to date. Although we conclude that ecosystem services have played at best a marginal role in norm change thus far, we argue that it presents two kinds of unheralded promises to contribute to this important project, via broadly shared values of justice and equity, and the identity-forming role that cultural ecosystem services have historically played. Highlighting relevant emerging institutions for ecosystem services, we propose an agenda for scaling these up and including a broad base of corporations and citizens in doing so, in part via a new initiative called CoSphere (a community of smallplanet heroes). We close by considering the kinds of governance challenges that any such initiative must address to normalize conservation.

\section{Ecosystem Services: The Great Green Hope?}

The rapid rise in popularity of the ecosystem services concept stems partly from the hope that it might normalize conservation. The argument can be phrased as follows: given the underpinning role of biodiversity in the production of benefits that are directly connected to people's daily lives, ecosystem 
services might embed conservation activities in a wide range of decisions where biodiversity per se lacked traction (Daily 1997; Balvanera et al. 200I).

Indeed, the Economist's first major coverage of ecosystem services embodied such logic (Economist 2005): if people could profit from ecosystem-service protection, well, that was the kind of concept that could rescue environmentalism (from the 'death' of the movement that had been declared months earlier). Although this media attention followed closely after the publication of the Millennium Ecosystem Assessment (Millennium Ecosystem Assessment 2005), the Economist articles primarily covered corporate action to pay for conservation that mitigated risks to future business. The focus on reducing risks and expanding business opportunities appealed most to corporate actors (World Resources Institute (WRI) et al. 2008).

Meanwhile, in government circles, ecosystem service approaches appeared to gain traction based on the logic that explicit valuation of ecosystem services would enable cost-benefit analyses to assist policy making and provide other processes to 'mainstream' conservation in decision-making (TEEB 2009; Daily et al. 20II).

Similarly, non-governmental organizations saw great potential for the ecosystem services concept to inspire new members and donors to conservation causes. Thus, conservation non-governmental organizations (NGOs) have been among the greatest popularizers of the concept, including through planning (Chan et al. 2006; Chan et al. 20l lb), on-ground programs (Goldman-Benner et al. 20I2) and also monetary valuations of nature's benefits to people (Naidoo \& Ricketts 2006; Turner et al. 2007; Naidoo et al. 2008).

With ecosystem services, conservation was no longer just for those who cared about the protection of rare species or actively sought to expand protected areas. The ecosystem services concept created the link to help people understand that anyone who drinks clean water and breathes clean air should care about environmental protection, both in remote areas but also close to home.

\section{Expanding the Tent or Welcoming the Wolf?}

The concept of ecosystem services is at the heart of the controversy over 'new conservation.' Proponents of 'new conservation' argue that old methods were failing, requiring the experimentation with and adoption of approaches that speak to the masses (Marris 20I I; Kareiva et al. 2012; Kareiva 20I4; Marris 2014). Whereas many see nature's benefits to people as a strong basis for conservation (Marvier \& Wong 20I2), the relevance of intrinsic values of biodiversity is the subject of considerable debate. Moreover, at least in concept, the idea of ecosystem services might provide many firms with diverse reasons for engaging in conservation, both to manage risks and to realize new opportunities (World Resources Institute (WRI) et al. 2008).

Of the numerous fierce critiques of this utilitarian turn to modern conservation, several are pertinent here: the contentions that (a) engaging with corporations and neoliberal market-based schemes associated with ecosystem services naively imagines that it can reverse the very forces that pose greatest risks to nature (Foster 2002; Peterson et al. 2010); (b) including instrumental motivations associated with ecosystem services will narrow the range of appropriate motivations (Norton \& 
Noonan 2007; Vatn 2010; Doak et al. 2015) and detract from 'real' conservation of biodiversity (McCauley 2006; Soulé 2013); (c) partnering with powerful industry forces will distort conservation agendas away from the most pressing matters, such as the structure of the economy (lgoe et al. 2010); (d) management for ecosystem services will not necessarily yield the biodiversity protection that conservationists seek, despite frequent claims that ecosystem services are ultimately dependent on biodiversity (Chan et al. 2007; Vira \& Adams 2009; Norgaard 2010); (e) valuation, economic metaphors, and market-based mechanisms may foster the commodification of nature and perhaps thereby undermine conservation agendas (Gómez-Baggethun \& Ruiz-Pérez 20I I; Luck et al. 20I2) and social justice (e.g., by obscuring the unequal power relations implicit in production) (Kosoy \& Corbera 2010).

Controversy over these issues has persisted even though the field of ecosystem services (which includes a suite of related terms studied in diverse fields, including 'environmental services') is actually much broader than the narrow economic-ecological framing that arguably popularized the idea over the past two decades. Recently, much broader conceptions of ecosystem services have received recognition in academic and policy circles, for example steering towards a more inclusive terminology to represent diverse ways of knowing (Díaz et al. 2015), and acknowledging a broader diversity of value concepts (IPBES (Intergovernmental Science-Policy Platform on Biodiversity and Ecosystem Services) 20I5; Chan et al. 2016). It is possible that if the field of ecosystem services had matured earlier in these ways, it would not have generated the same kind of controversy. Conversely, it is also possible that the field's strong ecological-economic and neoliberal focus generated the attention of government agencies and multinational corporations that was necessary for the field to blossom at all.

Although the above debates are lively and acrimonious, we know of scarce empirical examination of the net effect of ecosystem services research and practice on 'core' conservation activities and their normalization. One important study, however, found that ecosystem services projects conducted by the Nature Conservancy brought in new funding from an expanded set of funders, and that they were just as likely to include or create protected areas as projects without explicit ecosystem-services language (Goldman et al. 2008). Not only is there reason to believe that uptake of ecosystem services valuation in decision-making is limited (Honey-Rosés \& Pendleton 2013; Förster et al. 20 I5; Martinez-Harms et al. 20I5), there is a notable absence of empirical work on this topic (Laurans et al. 20I3). There is some evidence that implicit ecosystem-services framings do not crowd out diverse metaphors for human relationships with nature (that questions about benefits associated with ecosystems elicit a wide variety of views of nature, well beyond a factory model of production) (Klain et al. 20I4; Gould et al. 20I5). Furthermore, ecosystem-services applications are often sought without the request for monetary metrics (Ruckelshaus et al. 2015). Overall, has the concept of ecosystem services expanded the scope for conservation without diluting conservation's central objective of biodiversity protection? Empirically, it's too early to say.

\section{Norm Change in Conservation}

Social scientists, in diverse fields including anthropology, sociology, and psychology, have extensively explored factors that contribute to or impede widespread environmental attitudes and actions. These include, for example: connection to nature, sense of place, social identity and social networks (e.g., Gifford 20II). While abundant knowledge exists to aid the project of norm change for conservation, the 
fields of conservation and ecosystem services have given scant attention to the challenge of norm change. How might conservation engage with norm change more explicitly, and how might this relate to ecosystem services? Drawing on the above social science research, we identify four gaps in conservation practice and outline how a new approach might foster broad-scale norm change.

The first gap is that conservation science and practice has focused on behaviour, through a variety of efforts that do not easily scale up to norm change. The conservation community has increasingly recognized that conservation is fundamentally a human challenge, fuelling the recent rise of interest in the application of behavioral economics to conservation (e.g., Brondízio et al. 2010; Muradian et al. 20I3), and in the emerging field of conservation marketing (e.g., Veríssimo 20I3; Wright et al. 20I5). Behavioural economic approaches often 'nudge' behaviour change by making the desired behaviour easier and the default option for a specific situation, minimizing inconvenience and mental effort (Thaler \& Sunstein 2008). However, these behavioural approaches fall short of a norm-change agenda unless they engage values or social sanctions (the 'moral tinge'), which are crucial for norm enforcement (Fehr \& Fischbacher 2004). According to psychologist Cialdini (2003), norms are the values, customs, traditions and other 'cultural products' that represent individuals' basic knowledge of what others do and what they think they should do. From a social psychology perspective, norms are not behaviour per se, but rather "mental representations of appropriate behaviour" (Aarts \& Dijksterhuis 2003). In contrast, some sociological perspectives emphasize the role of formal and informal social sanctions in maintaining norms by rewarding or punishing behaviour (suggesting sanctions via external social pressure can be more powerful than individual beliefs)(Elster 2000; Hechter \& Opp 2001). Stemming from sociology, a social practice perspective explicitly accounts for the centrality of norms (including institutions and personal habits) in constraining and determining actions, which these scholars refuse to term 'behaviour' to explicitly de-emphasize the role of individual choice (Shove 2010). Regardless of these differing emphases, norm change can be much more powerful than mere behaviour change alone, because norms apply to diverse contexts (Reno et al. 1993).

Second, conservation has suffered from focusing unduly on those who are already motivated by environmental causes. As norms establish what is done routinely and what is seen as morally requisite, they can contribute powerfully to both environmental successes and failures, depending on the perceived status quo (Gifford 20l I). Norms, such as those for pro-environmental behaviour, often have prescriptive force only for those with a shared identity (Lapinski \& Rimal 2005), and often help to shape a group's identity (Feldman 1984). These points are crucial when one considers the kinds of behaviourchange interventions that are popularly alluded to in contemporary conservation. Many campaigns and actions appear to have appeal and uptake only amongst die-hard environmentalists, emphasizing the distinction between environmentalists and everyone else. Such segmented normalization might impede broad uptake of certain practices, leaving non-environmentalists to reason: "Environmentalists ought to do X", "I don't want to do X I X is too onerous", and therefore, "I am not an environmentalist." Conversely, the alternative reasoning is also true: "Environmentalists do X", "I am not an environmentalist (nor do I want to be)", therefore I will not do X”. Following this logic, we might understand why even people with environmental values may not develop the norms, behaviour, and shared identity of environmentalists or conservationists. Namely, when actions are perceived to be too onerous or undesirable, and/or individuals do not wish to identify as environmentalists, they may not ascribe to these group norms. Recent research suggests that negative stereotypes of environmentalists 
are common and may be associated with a reduced desire to affiliate with them and to espouse the behaviours they promote (Bashir et al. 20I3). Further, when people anticipate feeling morally judged by groups who deviate from the status quo, they tend to derogate these groups rather than adopt the norms and behaviours common to the group (Minson \& Monin 20I2). Thus, rather than making conservation part of everyday thinking and action, some efforts for civic behaviour change may actually impede widespread normalization.

As an illustrative example, all of the authors have experience with seafood purchasing campaigns, and one of us $(\mathrm{KC})$ routinely asks audiences about their experiences with them. Audiences relate strongly as evidenced by familiar laughs and nodding heads - to the discomfort of purchasing sustainable seafood. Asking restaurant servers detailed and apparently nitpicky questions about the source of an edible marine product, amidst several trips back to the kitchen to ask the chef, can be socially awkward and potentially disruptive. The problem here is that this action-as but one example of what is seen in some circles as being expected of good environmental citizens-brings embarrassment and so impedes normalization (group norms are generally behaviors that avoid embarrassing interpersonal experiences (Feldman 1984), not facilitate them). And even where there are norms, the norm-activation model suggests that anticipated feelings of pride help to activate those norms in the form of behaviour, and anticipated guilt impedes activation (Onwezen et al. 20I3). Only for a committed few is it more embarrassing to be caught consuming Patagonian toothfish or farmed Atlantic salmon than it is to bewilder one's server with questions she or he cannot answer. Thus, the gulf between environmentalists and the rest of the population widens.

A third gap is that while some environmental practices and values have extended beyond special interest groups to become normalized in general populations, these successes are generally quite limited in their scope and applicability. For example, reusable shopping bags used to be normal only for die-hard environmentalists, in part thanks to popular NGO campaigns depicting the devastating effects of plastic on seabirds, sea turtles, and other marine life. Reusing shopping bags has become normal for lots of people in many places (Clapp \& Swanston 2009), owing both to campaigns encouraging environmental citizenship and fiscal incentive policies (Dobson 2007). Two other conservation marketing examples highlighted by Wright et al. (2015) demonstrate the effect of increased public awareness on conservation behaviours: a seafood purchasing campaign involving a London luxury department store, Selfridges; and concerns for marine mammals in captivity promulgated by a team of NGOs and the movie Blackfish.The seafood purchasing campaign sought behaviour change resulting in consumers purchasing more sustainable seafood. The Blackfish campaign sought changes in behaviour (public attendance at orca shows), policy (a California bill banning captive orcas) and practice (changes to SeaWorld practices). Both were important and successful, raising awareness, educating people, and yielding changes in how some people buy seafood and in how SeaWorld housed orcas (they subsequently announced they are phasing out captive breeding, such that the current generation of orcas will be the last). However, such successes are very limited in scope, and so may contribute little to making conservation-writ large- normal.

Fourth, conservation has often sought normalization by leading with legislation, which can yield unintended consequences for conservation attitudes by overly restricting agency. Laws and policies can contribute eventually to actions being seen as morally requisite, which is crucial for normalization. But when a law or policy heavily burdens some people without their voluntary involvement and/or a broad 
base of support, it can impede positive norm change by provoking resentment and perverse behaviours. For all the great outcomes that have come from the US Endangered Species Act (Goble et al. 2005; Scott et al. 2006), it provides a prime example of this by burdening landowners found to host endangered species with large restrictions on land-use, which in turn incentivizes a perverse behaviour called "shoot, shovel, shut up" (Polasky et al. 1997). Personal agency appears to be key to conservationfriendly sentiments: engaging landowners in conservation in a voluntary capacity has yielded large changes in compliance and attitudes (Wilcove \& Lee 2004). In contrast to the Endangered Species Act, the aforementioned bill banning keeping orcas in captivity was an example of first establishing the moral norm among the populace, then achieving legal progress. 'Growing your people' (Heath \& Heath 2010) - in this case via cultivating conservation-supporting identities (even without self-identification as environmentalists) - is important for achieving policy or institutional change supported by a critical mass of individuals (Burstein 2003).

Considering these gaps, one might argue that what conservation needs to achieve widespread norm change is to give a wide diversity of people the opportunity to enact-conspicuously-a broadly shared value via a sweeping set of conservation-relevant actions that are easy, enjoyable, and not too expensive. By rooting the actions in values, and making them conspicuous (for reinforcing social sanctions), we might move beyond behaviour to the realm of norms. By connecting to broadly shared values, and making the actions easy, enjoyable and not too expensive, we might reach beyond the environmental movement to broader publics. By connecting a sweeping set of conservation-relevant actions under the same umbrella, we might include a broad scope of conservation challenges. And by giving people options, we might 'grow our people' and avoid the pitfalls of solutions that overly restrict agency. Before we consider what kind of a program might simultaneously achieve these various requirements, we must first consider the role of ecosystem services.

Of the normalizing conservation successes we know, precious few have stemmed from ecosystem services research and practice. Most seem to stem from a strong principle- or virtue-based position, such as the recent popular views strongly opposed to trophy hunting, notwithstanding apparent contributions from trophy hunting activities to conservation funding (Chan 2015; Di Minin et al. 20I6). Other examples of emerging normalization in conservation include (as above) the view that it is wrong for retailers to sell seafood that catches sea turtles, dolphins, and seabirds; that it is wrong to keep intelligent and emotionally complex animals in small tanks; or, in the case of the many successful Rare Pride campaigns, that a particular endangered animal is a cherished component of a place and the responsibility of its citizens (Jenks et al. 2010). Pollution-motivated laws and policies, such as the US Clean Water Act, which requires the protection and compensatory restoration of wetlands, have impacted industry practice but with only limited consequences for conservation. For the most part, ecosystem services research and practice has steered clear of such moral territory (but see Luck et al. 2009; Chan et al. 20I la; Chan et al. 20 I2b; Luck et al. 20I2; Jax et al. 20I3). We see this largely uncharted moral territory related to ecosystem services as a key opportunity, because the ecosystem services concept offers a critical benefit in the building of norms for conservation. 


\section{The Uncelebrated Promise of Ecosystem Services: I. Justice}

Ecosystem services research and practice have widely overlooked principle-based arguments for conservation. Whereas intrinsic values in nature are widely recognized (e.g., the rights of non-human species to exist), but often seen as secondary to human considerations (Marvier \& Wong 20I2), the ecosystem services concept explicitly connects the environment to human consequences (Daily 1997). Because these human consequences can be distributed fairly or unfairly, ecosystem services connect environmental issues to strong normalizing concepts such as justice and equity (Rawls 197I). Yet, the ecosystem services field has largely aligned itself with a strictly utilitarian logic (but see Sikor 2013), which is largely silent on justice considerations (Dean Moore \& Russell 2009; Chan \& Satterfield 20I3). The alignment of ecosystem services with utilitarian logic likely stems from the key role of economics in the field's origin (Gómez-Baggethun et al. 2010), but the time is ripe for a broadening in this moral framing (Luck et al. 2012; Jax et al. 2013; Chan et al. 2016).

The moral and normative promise of the ecosystem services concept is that it extends 'responsibility,' a powerful moral concept, through space and time and across environmental contexts. Responsibility is inherent in the Golden Rule (do unto others as you would have them do unto you-were you in their position) (Hare 1991), a foundation for a wide array of moral frameworks. All people rely on and benefit from ecosystem services, albeit some much more directly than others (Bawa \& Gadgil 1997). Most of us would not want these services degraded, as routinely occurs every day via pressures associated with human consumption of various goods and services, including extraction, production, transportation, etc. (MA 2005). It follows then that most of us would recognize a responsibility to use ecosystem services thoughtfully and sustainably as an extension of our responsibilities towards other people. Current supply chains, one might argue, are unjust in their propagation of environmental impacts via pollution, habitat loss and degradation, etc., with limited opportunity for consideration or mitigation. One meaningful step to restore justice would be mitigating our impacts on ecosystem services to reduce disproportionate impact on impoverished and disempowered peoples (Bawa \& Gadgil 1997; Martinez-Alier 2002).

Recognizing and leveraging the relevance of ecosystem services research for justice does not imply resorting to a new manifestation of moral suasion (behaviour change via moral argument). Our position here is rather that ecosystem services have crucial justice dimensions, and that these might be leveraged into broadly shared changes in behaviour or 'social practice' by creating the institutions and infrastructure that enable actions that align with those core values (Shove 2010). In the final section we discuss the institutions and infrastructure that might enable consumers, corporations, and producers to mitigate impacts on ecosystem services, in line with environmental dimensions of justice. First, we consider a second important lever provided by ecosystem services-this time associated not with the concept but rather the services themselves.

\section{The Promise of Ecosystem Services: 2. Value Formation}

Ecosystem services offer a second major leverage point for making conservation normal, in that cultural ecosystem services contribute crucially to the formation of relationships with 'nature', and to values about those relationships (relational values) (Chan et al. 2016). A purely instrumental relationship with 
nature is unlikely to inspire concern for distant people and places. More likely, concern for conservation will stem from a citizen's knowledge of, attachment to, and identification with places/ecosystems/species and associated people.

Cultural ecosystem services, as "ecosystems' contributions to the non-material benefits (e.g., capabilities and experiences) that arise from human-ecosystem relationships" (also see Church et al. 20I I; Chan et al. 20I2b), are a primary conduit for establishing and renewing strong relationships with nature (MartínLópez et al. 2012; Plieninger et al. 2013; Klain et al. 2014; Chan \& Satterfield 2016). Arguably, it is the non-material experience of ecosystems (a cultural service) that propels people to seek out further experiences, even if a provisioning service is also implicated (e.g., provision of fish for subsistence, recreational, or commercial catch) (Chan et al. 2012a). From these repeated interactions arise capabilities (e.g., boat-handling, navigation, reading the weather, knowledge of submerged rocks and currents, cleaning and cooking fish), norms, and identities (Chan \& Satterfield 2016). Surely it is such lived experiences, norms and identities that provide a substantial basis to care for places, and about other places (Norton \& Hannon 1997; Scannell \& Gifford 2010a; Scannell \& Gifford 2010b; Chan et al. 2016).

Arguably, these tangible and intangible relationships with nature are essential to value formation. Given the demographic changes of the 2 I st Century, the majority of human beings live in cities and have experienced a dramatic rise in the substitution of virtual (screen-based) experiences for outdoor ones (but see McLain et al. 2014; Poe et al. 20I4; Chan et al. 2016; Chan \& Satterfield 2016). Louv's (2008) reference to the "last child in the woods" is no joke. Meaningful experiences in nature during childhood and over time, especially experiences intertwined with important people in our lives, can greatly influence our values and relationships with nature as adults, and these values can inspire conservation action (Clayton \& Myers 20I5; Poe et al. 2016). Accordingly, ecosystem services are central to the project of normalizing conservation because they are crucial to the formation of environmental identities (including values) upon which conservation relies. Efforts to mainstream conservation must therefore foster the kind of contact with ecosystem services (particularly cultural ones) that fosters attachment and broader environmental identities.

\section{Innovations and Institutions for Conservation in the Anthropocene}

Above we argue that a justice-based ecosystem services concept holds promise as an additional moral basis for conservation - that we ought to protect and restore the ecosystems upon which we all rely. To move from a principled idea to norm change will require enacting the idea via practical solutions from bold individuals and organizations. Particularly important are the actions of businesses, churches, universities, and governments that have demonstrated a willingness to make principled purchasing and investments (or divestments). Also crucial are affluent individuals (in the middle and upper classes) whose consumption has disproportionate impact, and who have the capacity to pay to mitigate their impacts (via improved practices and offsets). Here we briefly discuss existing mechanisms that integrate consideration for ecosystem service impacts, including certification, community supported fisheries, and payments for ecosystem services. The key question is how new institutions might combine aspects of these strategies and amplify their application at broader scales. Towards this end, we introduce 
CoSphere, a new initiative aimed at spreading norms of environmental responsibility that exemplifies our vision.

\section{Promising Institutions for Ecosystem Services}

Apart from those relying entirely and directly on ecosystems for subsistence, we all participate in market economies rooted largely in unsustainable use and degradation of oceans and other ecosystems. Several existing strategies disrupt traditional supply chains to engage consumers, and address particular environmental concerns. We highlight a few important examples.

Certification: Certification systems provide one means of reducing environmental degradation, via third party evaluation of certain production practices, but challenges remain. As one example, Marine Stewardship Council certified products, like products labelled under other certification systems, are available in some places for some product types, for an additional cost (often a considerable barrier). They likely confer reduced impacts on ecosystems and ecosystem services, but important residual impacts undoubtedly remain (Jacquet et al. 20l0b). Furthermore, certification systems present consumers with a plethora of choices and information that most people are not equipped or interested to deconstruct (Jacquet et al. 20I0a).

Community Supported Agriculture/Fisheries: Based on the logic that overexposure and vulnerability to risk prevents individuals and companies from adopting new approaches that might yield environmental gains (Holzmann \& Jørgensen 200I), new strategies like community supported fisheries are appearing to help fishers manage risks, following the community supported agriculture model (Brinson et al. 20II). As a conservation strategy, it is indirect, providing a guaranteed revenue stream via membership fees collected at the outset of the season. This certainty and timing of funds may help fishers (especially small-scale ones, who may lack access to capital) invest in repairs, new gear, upgrades, and otherwise undertake sustainable practices including avoiding bycatch and targeting appropriate species. In practice, community supported fisheries can help reduce greenhouse gas emissions, and they may help address other environmental problems (McClenachan et al. 2014).

Payments for Ecosystem Services (PES): PES programs are institutionalized payments to ecosystem service providers to improve or reduce impacts on ecosystem services (Wunder 2006; Jack et al. 2008; Schomers \& Matzdorf 2013; Wunder 2013). Existing designs have yielded mixed results (Kinzig et al. 201 I; Naeem et al. 20I5) and suffered from a wide range of critiques (Muradian et al. 2013; Pascual et al. 2014; Chan et al. in review), but some of us have argued elsewhere that a subtle but important redesign of PES could largely address most of the largest critiques (Chan et al. in review). For example, by changing the program framing (to be a reward for leadership in land management) and by offering only a copay, programs could avoid crowding out existing motivations for conservation and distribute responsibilities more evenly so as to avoid 'paying the polluter' (for pollution reductions that could be seen as extensions of pre-existing responsibilities). And by paying for a wide range of management actions, programs can enlist (rather than squash) landowner agency and creativity (Chan et al. in review). Despite perceptions of widespread application of PES, PES programs have spread slowly in some contexts (Wunder 20I3). 
Insofar as certification, community-supported agriculture/fisheries and PES programs could contribute to the maintenance of sustainable ocean- and land-based livelihoods (by providing an additional revenue stream), an expansion of these initiatives could foster the continued exposure to cultural ecosystem services that build key capacities for using nature and attachments to it (Chan \& Satterfield 2016).

\section{Novel and Scaled-up Institutions}

To attain broad normalization of conservation, a crucial step is to enable all those who are complicit in environmental degradation to mitigate their impacts via mechanisms that are conspicuous, easy, enjoyable and not too expensive.

Since many of these impacts are entailed by purchases of products and services, such mitigation opportunities would ideally be linked to purchases (via payments commensurate with the embodied impacts; probably as an opt-out to signal a default and norm of paying (Heath \& Heath 20I0; Kahneman 2013)). Imagine walking into a grocery store and being able to buy a wide variety of seafood products, knowing that coupled with your purchase of the shrimp (for example), would be a payment that funds fishers and conservationists to prevent bycatch and restore the species and habitats harmed in fishing.

Some of the authors are working to create and propagate such mitigation opportunities via CoSphere (a Community of Small Planet Heroes, Ecologically Regenerating Economies). This fledgling organization is building critical institutional infrastructure for sustainability and an online community to enable consumers and organizations to improve their environmental impact. When all members of the supply chain, in partnership, can take shared responsibility for their negative impacts, pledge their commitment to improve impacts, and take action to achieve such improvements, we can initiate a movement toward market transformation (see Figure 2).

CoSphere's developers hope that by enabling individuals and firms to have net-positive impacts on our planet's biodiversity and ecosystem services, it can unleash stewardship values across the supply chain. These positive impacts would be achieved via contributions to conservation and stewardship programs directly, in the form of creative financing as described above, payment for ecosystem services programs (Chan et al. in review), and impact investing, including social impact bonds (see below).

CoSphere would be akin to a system of offsetting for biodiversity and ecosystem services, but it would learn from failures in carbon offsets (Bumpus \& Liverman 2008; Corbera et al. 2009; Wittman \& Caron 2009; Wittman et al. 2015) — that have arguably given offsets a bad name—and ongoing learning about biodiversity offsets (BBOP20I2b; BBOP20I2a; Miller et al. 2015; Moreno-Mateos et al. 20I5; Tallis et al. 20I5). In particular, three points are key. First, offset transactions would be negotiated by an armslength third-party organization (Fox et al. 2006), not open to trading as are commodities, so as to avoid speculation and profiteering. Second, payments would go primarily or exclusively to on-ground conservation, restoration and improved resource management, rather than to companies who manage to find room under artificial 'caps' as in a cap-and-trade model. Third, messaging would target earnest responsible citizens and organizations to convey clearly that CoSphere is aimed at market transformation (rather than a means to justify consumption).

Existing pathways to support sustainability build on consumer demand for specific products, whereas transformation and norm change requires innovation at the system-level. CoSphere aims for system- 
level transformation in several respects. First, by rooting a conspicuous, easy, and enjoyable action (paying for mitigation) in a broadly shared value, it intends to take advantage of positive social sanctions toward norm change. Second, by inviting citizens and corporations alike, it hopes to enable consumers to pressure retailers to mitigate impacts, retailers to require suppliers, and so on down supply chains (and also back up, e.g., via progressive retailers marketing their commitment to consumers). Third, by providing funds directly to on-ground conservation and stewardship, including fishers, farmers, etc., this model would foster the ongoing development of connections to the ocean and the land upon which environmental identities are based. Below we describe how regenerative renewable energy and new investment strategies present two potentially impactful pathways to increase visibility and personal connections to ecosystem services, while supporting their restoration.

A likely impediment to the normalization of conservation stems from the ever-present cognitive dissonance for consumers who desire to propel environmental solutions but know that chosen solutions cause other environmental harms. Renewable energy infrastructure, for example, has been opposed in many places, in part due to its impacts on ecosystem services and biodiversity. Specifically, whereas offshore wind turbines could contribute substantially towards meeting electricity demand in numerous coastal countries (Jacobson et al. 2015), they pose a threat to some species of seabirds and migratory birds. Perhaps innovation in the energy sector could tap into latent willingness to pay for biodiversityfriendly renewable energy development, mitigating the impacts of this otherwise 'clean' technology. Klain and colleagues (in prep.) document high willingness to pay-over $\$ 35 /$ month/person-for offshore wind farms that enhance species diversity and abundance via artificial reefs at the base of the turbines. This willingness to pay for biodiversity friendly energy could possibly fund not only the deployment of artificial reefs in association with offshore wind farms, but also seabird nesting habitat protection, conservation in migratory flyways, and other conservation and restoration activities. No energy is entirely free of negative impact, but CoSphere would aim to enable consumer purchases that bundle renewable energy with the onsite or offsite mitigation of residual impacts.

For conservation to be broadly normal, citizens ought to be able to express their conservation values through their investment choices without great difficulty or cost. For example, CoSphere intends to enable conservation impact investing (Olmsted \& Chan in prep.), via a model based on social impact bonds (SIBs). SIBs are a relatively new financial mechanism currently being rolled out in several UK and US locations and gaining interest and traction with other regional and federal governments globally (Warner 2013). Briefly, they are a contract between the private and public sectors where private capital is used to fund a social program, with the government committing to pay back the investor with a return when the investment results in improved social outcomes and public sector savings (Figure I).

Application in the environmental sector is limited to infrastructure and energy projects; in conservation projects are less likely to generate returns and so it is more difficult to follow the traditional SIB model and by which cost savings are recouped (Olmsted 2016). We do see potential for a similar model, however, that includes up-front support from a foundation or government to match crowd-funded community contributions. We refer to this arrangement as a 'stewardship bond', because the finances would be raised primarily by those who live or operate in a region, with the explicit intent that this support would foster a sense of stewardship that previously was latent (such that investors would be truly 'invested' in the region). 


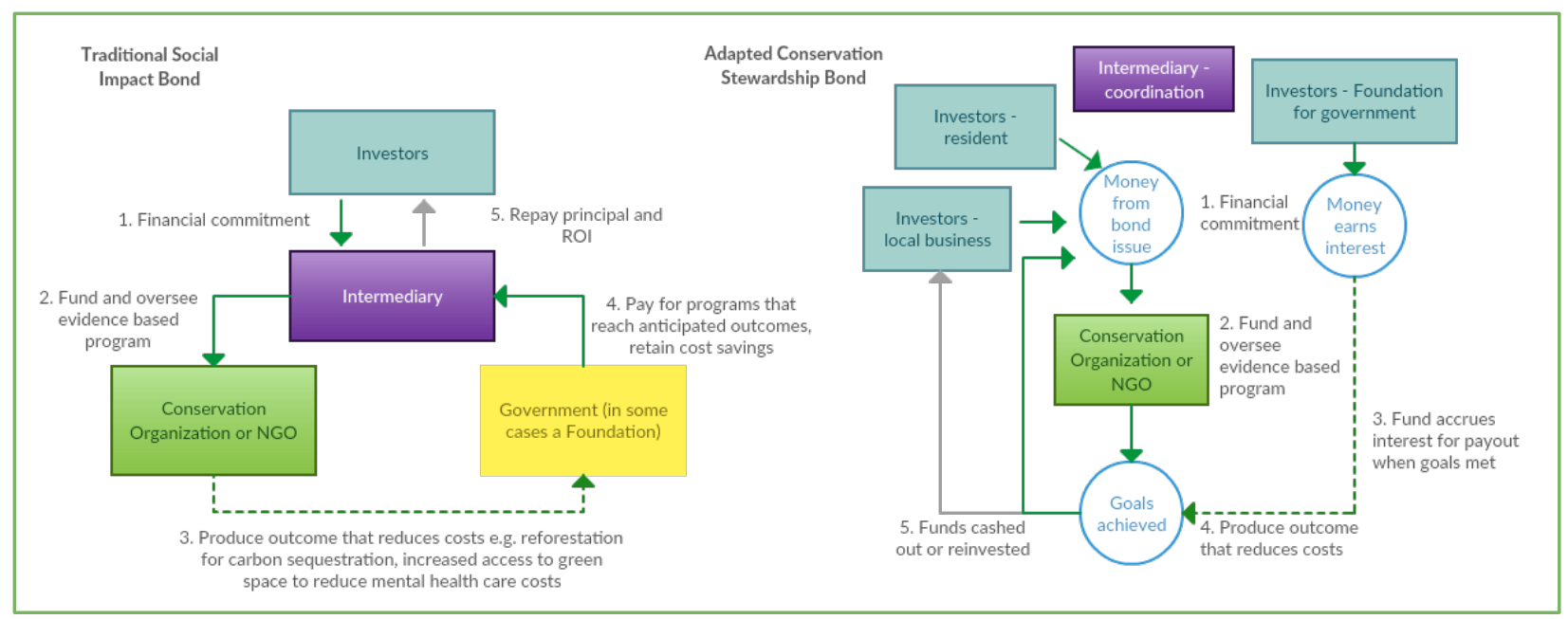

Figure I. Schematic representing traditional social impact bonds and an adaptation of these for conservation, to enable expression of conservation values via investments to restore ecosystems and ecosystem services. In the traditional model, an up-front financial commitment facilitates a conservation effort that results in a cost savings. This savings enables a return on investment paid to the investor after agreed term. The adapted model does not require explicit cost savings. For example, crowdfunding from residents and local businesses fund a wetland restoration. Matching foundation funds are set aside to generate a small percentage of return. If the conservation goals are met, supporters would have the option to 'cash out', or re-invest to projects as in a revolving fund.

Since stewardship bonds would not be a traditional donation, and there is the opportunity for (modest) financial gain, they may increase the financial support for conservation projects while attracting new people who would not otherwise participate, broadening the tent on the path to normalization (Olmsted 2016). Furthermore, the modest nature of the potential financial gain is both intentional and instrumental, for several reasons. First, CoSphere would be intended for investors with genuine concern for local outcomes, not those seeking to 'make a quick buck'. Second, a modest payoff should be sufficient such that diverse investors (including stakeholder groups that do not normally collaboratee.g., the fishing industry, local property owners, other industry and retailers operating in the region, and conservation NGOs) see the benefit in collaborating to achieve the ecosystem service protection targets. (All would receive the payoff on the same schedule.) Third, modest gains should lead investors to feel that they could have maximized returns elsewhere, which ought to foster the avoidance of cognitive dissonance (Festinger 1962; Cooper 2007) to consolidate local stewardship values and identities (because accepting lower returns only seems rational if a person is committed to the cause).

\section{Good Governance and Institutions That Fit}

Controversies about due process and human casualties pose a major risk to the widespread normalization of conservation, as illustrated by the Death of Environmentalism (Shellenberger \& Nordhaus 2004), conservation refugees (Dowie 2005), and Chapin's challenge to conservationists (2004). Ecosystem services are intended to address human well-being in conservation, but the risk remains that lofty ideas are applied in inappropriate and even harmful ways on the ground, perhaps especially with innovative "big picture" conservation solutions. For example, the negative impacts of and inappropriate processes through which well-intentioned and globally accepted models of conservation 
and ecosystem services (e.g., terrestrial and marine protected areas; carbon markets) are well documented (West \& Brockington 2006; Bumpus \& Liverman 2008; Corbera et al. 2009; Wittman \& Caron 2009; Bennett \& Dearden 20I4; Franco et al. 20I4; Wittman et al. 2015). Persistent critiques have led some to question the effectiveness of capital-driven conservation programs (Brockington et al. 2008; Brockington \& Duffy 20 II). Yet, we argue that in the friction between global conservation programs and local practices there is the opportunity to create institutions that are legitimate, enabling and sufficiently flexible to fit diverse contexts. In institutions intended to normalize conservation, we would highlight two key strategies to overcome the challenges discussed above.

First, the decision-making bodies and the processes through which decisions are made need to employ good governance in order to ensure the acceptability and legitimacy of the initiative. Thus, good governance is crucial not only for its own sake, but also for practical or instrumental reasons. The concept of "good" governance suggests that there is a right way (and hence, a wrong way) to do things. Normative ideals—such as inclusiveness, participation, deliberation, vision, voice, equity, transparency, and accountability - are key considerations (Lockwood et al. 2010; Turner et al. 20l4). Local expectations or perceptions about who is at the table and the way that decisions are made about programmatic priorities, actions to be taken or projects to be funded can determine whether local people will support initiatives (Bennett 2016). These literatures suggest that decision-making bodies would need to incorporate local people, and their voices and visions, in transparent deliberation processes. Mechanisms would need to be in place to ensure those making decisions are accountable for social and ecological outcomes. 'Good governance' sounds obvious; achieving it in reality (not just rhetoric-Igoe 2004) is another matter.

Second, the way that decisions are made and actions employed need to be flexible enough so that they can be adapted to "fit" different contexts (Young 2002; Epstein et al. 20I5; Guerrero et al. 20I5). Many top-down conservation initiatives exclude local voices, values, needs and pre-existing governance arrangements (Smith et al. 2009; Bennett et al. 2015). Yet, when conservation programs do not align with local social, cultural, economic or governance contexts, they are unlikely to be deemed legitimate or adopted broadly (Hoffman 2009; Ban et al. 20I3). Without appropriate safeguards, corporate/private partners or even consumers in market-oriented conservation models such as CoSphere might drive the agenda and propose actions for local implementation with little knowledge of what would actually work. How can we ensure that this does not occur? Program infrastructure would need to ensure that governance and decision-making processes are adaptable and flexible enough to allow for these contextual differences, thus enabling locally appropriate, acceptable and effective solutions (Barrett et al. 2005; Folke et al. 2005; Ostrom et al. 2007). 


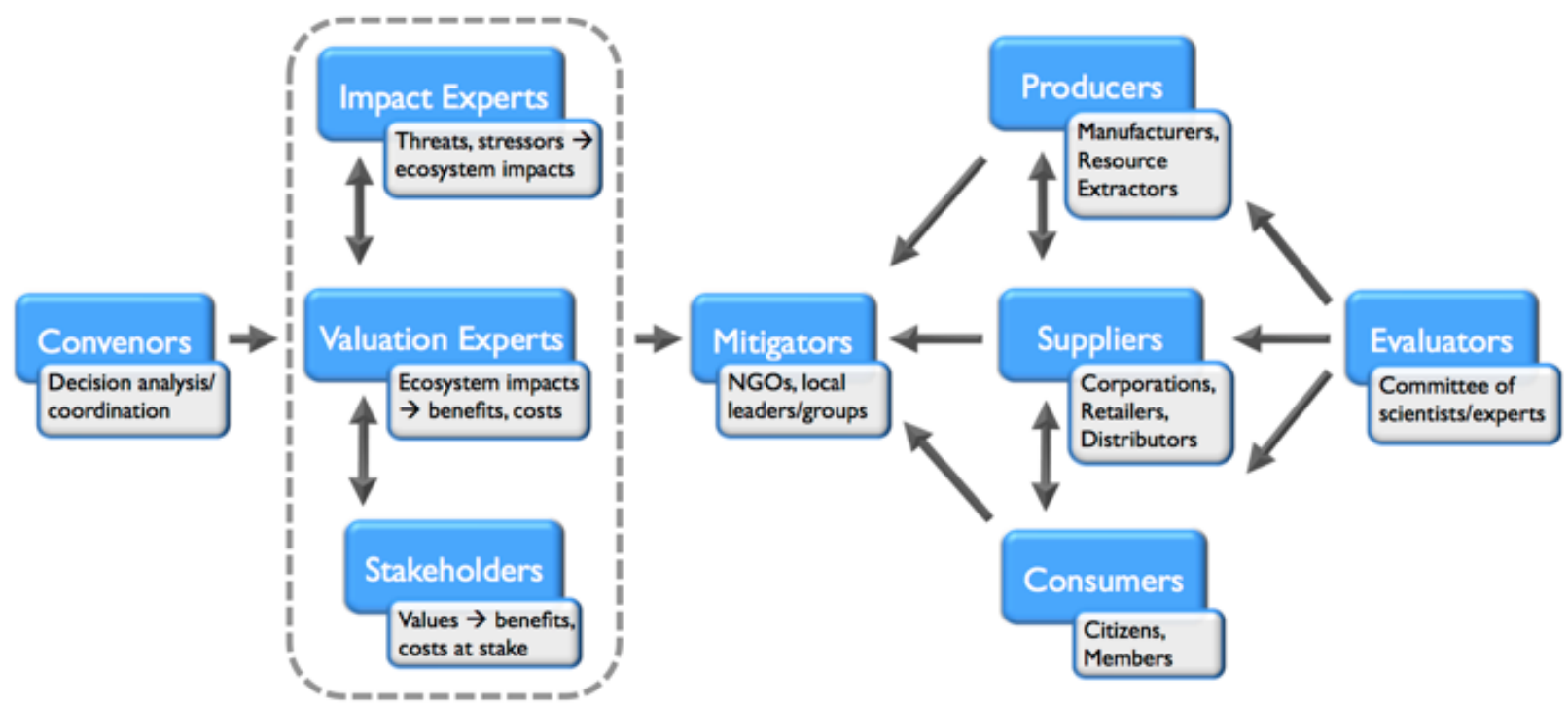

Figure 2. A schematic representing the institutional arrangements envisioned for CoSphere (a Community of SmallPlanet Heroes, Ecologically Regenerating Economies). On the left side, the convenors bring together a variety of local experts and stakeholders in a structured participatory process to prioritize the kinds of mitigation actions that would be most appropriate. On the right side, evaluators help producers, suppliers, and consumers identify needed kinds of impacts needing mitigation in different regions; based on this, CoSphere members (individuals and organizations) contribute funding for conservation.

Integrating these considerations in the context of initiatives such as CoSphere (which is but one example of the ideas introduced here), we see the following needs and solutions. To foster institutions that fit, institutions would need to be nested across scales, with a guiding principle of subsidiarity (i.e., decisionmaking authority delegated to the lowest level possible). At CoSphere, a global body would guide, enable and support regional or national bodies that would be entrusted with making decisions. These local decision-making bodies, made up of selected experts (i.e., scientists, practitioners, policy-makers, and community representatives), would be charged with crowd-sourcing proposals (to be funded through a kind of reverse auction scheme, Chan et al. in review), analyzing their effectiveness and negotiating across scales to select projects that are situated in context and that align with conservation and development priorities and locally salient ecosystem services (locally, nationally and globally) (Figure 2 depicts this, without the scalar complexity). To further ensure local accountability, regional conservation priorities would be derived from value-focused deliberative multi-stakeholder processes (Espinosa Romero 2010; Gregory et al. 2012). All told, the challenge is to embed good governance and participatory processes in a space (environmental management) too often occupied by a combination of highly constrained or even dysfunctional governmental agencies and private corporate control (Dauvergne \& Lister 20I3). 


\section{Conclusion}

Conservation is not yet normal, and yet it is an attainable goal. By leveraging the implicit potential of ecosystem services to put a human face on environmental change, conservation can legitimately link environmental concerns to social justice. We see hope, including via CoSphere, that conservation can address the five major concerns regarding ecosystem services we identified (see "Expanding the Tent or Welcoming the Wolf?"), (a) enlisting powerful economic forces without succumbing to them, (b) 'crowding in' inherent motivations for conservation, (c) addressing the structure of the economy in a subtle, inconspicuous way (by popularizing the internalization of ecological externalities), (d) protecting biodiversity as a target alongside ecosystem services, and (e) actively contributing to conservation values and social justice by funding ocean- and land-based people to continue traditional livelihoods and evolve them further towards sustainability. Pursuing this with a combination of incentive programs, finance schemes, and adaptable "good" governance institutions that engender not only behaviour change but also value change, conservation could become the new normal-both morally necessary and commonplace.

\section{Taking Action, Spreading Norms}

The above example of CoSphere is but one potential mechanism to spread conservation norms. Achieving transformational change will by definition require a groundswell of support that could not simply stem from one or two initiatives. Consequently, to support any readers who would like to spread conservation norms in their workplaces, families, and communities, we offer the following as starting points (while naturally welcoming any multitude of other strategies).

- Join and/or build a conservation initiative around an issue that already has community support to leverage existing areas of focus (e.g., local ecosystem services), connecting explicitly to stewardship and responsibility

- Frame messages to encourage connections between the environment/environmental values and broader values such as justice and equality, including via ecosystem services

- Engage stakeholders early in the process of a new initiative to promote buy-in and ownership via fair and inclusive processes

- Set great examples of actions in accordance with values-Social norms are powerful, and people tend to follow the lead of those around them

- Provide pathways for action that are easy, fun, and broadly inviting to help generate critical mass beyond self-identified environmentalists

\section{References}

Aarts, H. and A. Dijksterhuis (2003). "The silence of the library: environment, situational norm, and social behavior." Journal of Personality and Social Psychology 84(I): 18.

Balvanera, P., G. C. Daily, P. R. Ehrlich, T. H. Ricketts, S. A. Bailey, S. Kark, C. Kremen and H. Pereira (200I). "Conserving biodiversity and ecosystem services." Science 29 I (55I I): 2047-2047. http://www.sciencemag.org/cgi/content/full/291/55II/2047 
Ban, N. C., M. Mills, J. Tam, et al. (2013). "Towards a social-ecological approach for conservation planning: embedding social considerations." Frontiers in Ecology and the Environment I I: 194202. http://dx.doi.org//0.1890/I 10205

Barrett, C. B., D. R. Lee and J. G. McPeak (2005). "Institutional arrangements for rural poverty reduction and resource conservation." World Development 33(2): 193-197. http://www.sciencedirect.com/science/article/pii/S0305750X04001895

Bashir, N. Y., P. Lockwood, A. L. Chasteen, D. Nadolny and I. Noyes (2013). "The ironic impact of activists: Negative stereotypes reduce social change influence." European Journal of Social Psychology 43(7): 614-626. http://dx.doi.org//0.1002/ejsp.1983

Bawa, K. S. and M. Gadgil (1997). Ecosystem services in subsistence economies and conservation of biodiversity. Nature's Services: Societal Dependence on Natural Ecosystems. G. C. Daily. Washington, DC, Island Press: 295-310.

Bennett, N. J. (2016). "Using perceptions as evidence to improve conservation and environmental management." Conservation Biology 30(3): 582-592. http://dx.doi.org//0.1 I I //cobi.I268I

Bennett, N. J. and P. Dearden (20I4). "Why local people do not support conservation: Community perceptions of marine protected area livelihood impacts, governance and management in Thailand." Marine Policy 44(0): 107-II6. http://www.sciencedirect.com/science/article/pii/S0308597XI300I7II

Bennett, N. J., H. Govan and T. Satterfield (20I5). "Ocean grabbing." Marine Policy 57(0): 6I-68. http://www.sciencedirect.com/science/article/pii/S0308597X 15000755

Brinson, A., M.-Y. Lee and B. Rountree (20II). "Direct marketing strategies: The rise of community supported fishery programs." Marine Policy 35(4): 542-548. http://www.sciencedirect.com/science/article/pii/S0308597X II 000157

Brockington, D. and R. Duffy (20I I). Capitalism and Conservation, Wiley. https://books.google.ca/books?id=WDHZNEWqSQcC

Brockington, D., R. Duffy and J. Igoe, Eds. (2008). Nature Unbound: The Past, Present and Future of Protected Areas. London, Earthscan. http://books.google.ca/books?id=MOwOJwAACAAJ

Brondízio, E. S., F. W. Gatzweiler, C. Zografos, M. Kumar, X. Jianchu, J. McNeely, G. K. Kadekodi and J. Martinez-Alier (20I0). Socio-cultural context of ecosystem and biodiversity valuation. The Economics of Ecosystems and Biodiversity: Ecological and Economic Foundations. P. Kumar. London and Washington, Earthscan: 150-181. http://www.teebtest.org/2013-08-30 archive/wpcontent/uploads/2013/04/D0-Chapter-4-Socio-cultural-context-of-ecosystem-and-biodiversityvaluation.pdf

Bumpus, A. G. and D. M. Liverman (2008). "Accumulation by decarbonization and the governance of carbon offsets." Economic Geography 84(2): I27-I55. http://dx.doi.org// 0.1 I I //j.19448287.2008.tb0040I.x

Burstein, P. (2003). "The impact of public opinion on public policy: A review and an agenda." Political Research Quarterly 56(I): 29-40. http://prq.sagepub.com/content/56/I/29.abstract

Business and Biodiversity Offsets Programme (BBOP) (2012a). Resource Paper: Limits to What Can Be Offset. Washington, DC, BBOP: 39. http://www.forest-trends.org/documents/files/doc_3128.pdf

Business and Biodiversity Offsets Programme (BBOP) (20l2b). Standard on Biodiversity Offsets. Washington, D.C., Forest Trends. http://www.forest-trends.org/documents/files/doc_3078.pdf

Chan, K. M. A. (20I5). Trophy hunting: a bugbear for Christy Clark. Vancouver Observer. Vancouver. http://www.vancouverobserver.com/opinion/trophy-hunting-bugbear-christy-clark

Chan, K. M. A., E. Anderson, M. Chapman, K. Jespersen and P. Olmsted (in review). "Payments for ecosystem services: Rife with problems and potential—for transformation towards sustainability." Ecological Economics.

Chan, K. M. A., P. Balvanera, K. Benessaiah, et al. (2016). "Why protect nature? Rethinking values and the environment." PNAS I I3(6): |462-|465. http://www.pnas.org/content/ I 3/6/| 462.full 
Chan, K. M. A., J. Goldstein, T. Satterfield, N. Hannahs, K. Kikiloi, R. Naidoo, N. Vadeboncoeur and U. Woodside (20l la). Cultural services and non-use values. Natural Capital: Theory \& Practice of Mapping Ecosystem Services. P. Kareiva, H. Tallis, T. H. Ricketts, G. C. Daily and S. Polasky. Oxford, UK, Oxford University Press: 206-228. http://www.oup.com/us/catalog/general/subject/Economics/Policy/?view=usa\&sf=toc\&ci=97801 99 588992

Chan, K. M. A., A. Guerry, P. Balvanera, et al. (20I2a). "Where are 'cultural' and 'social' in ecosystem services: A framework for constructive engagement." BioScience 6(8): 744-756. http://dx.doi.org/I0.1525/bio.2012.62.8.7

Chan, K. M. A., L. Hoshizaki and B. Klinkenberg (20I Ib). "Ecosystem services in conservation planning: Targeted benefits or co-benefits/costs?" PLoS ONE 6(9): e24378. http://dx.plos.org/10.137//journal.pone.0024378

Chan, K. M. A., R. M. Pringle, J. Ranganathan, et al. (2007). "When agendas collide: Human welfare and biological conservation." Conservation Biology 2 I (I): 59-68. http://www.blackwellsynergy.com/doi/abs/10.1III/j.1523-1739.2006.00570.x

Chan, K. M. A. and T. Satterfield (2013). Justice, equity, and biodiversity. The Encyclopedia of Biodiversity. S. A. Levin. Oxford, Elsevier Ltd: 434-44I. http://store.elsevier.com/Encyclopediaof-Biodiversity/isbn-9780I23847/95/

Chan, K. M. A. and T. Satterfield (20I6). Managing cultural ecosystem services for sustainability. Routledge Handbook of Ecosystem Services. M. Potschin, R. Haines-Young, R. Fish and R. K. Turner. London and New York, Routledge: 343-358.

Chan, K. M. A., T. Satterfield and J. Goldstein (20I2b). "Rethinking ecosystem services to better address and navigate cultural values." Ecological Economics 74(February): 8-18. http://www.sciencedirect.com/science/article/pii/S092 I8009I I 004927

Chan, K. M. A., M. R. Shaw, D. R. Cameron, E. C. Underwood and G. C. Daily (2006). "Conservation planning for ecosystem services." PLoS Biology 4(II): 2I 38-2I 52. http://biology.plosjournals.org/perlserv/?request=getdocument\&doi= $10.137 \mid$ /journal.pbio.0040379

Chapin, M. (2004). "A challenge to conservationists." World Watch 2004(Nov/Dec): I7-3I. http://www.eldis.org/static/DOCI8II0.htm

Church, A., J. Burgess, N. Ravenscroft, et al. (20I I). Cultural services. The UK National Ecosystem Assessment Technical Report. UK National Ecosystem Assessment. Cambridge, UK, UNEPWCMC: 633-692. http://uknea.unepwcmc.org/LinkClick.aspx?fileticket $=Q$ LgsfedO70l\%3d\&tabid $=82$

Cialdini, R. B. (2003). "Crafting normative messages to protect the environment." Current Directions in Psychological Science I 2(4): I05-109. http://cdp.sagepub.com/content//2/4//05.abstract

Clapp, J. and L. Swanston (2009). "Doing away with plastic shopping bags: international patterns of norm emergence and policy implementation." Environmental Politics 18(3): 315-332. http://dx.doi.org// 0.1080/096440109028237/7

Clayton, S. and G. Myers (20I5). Conservation Psychology: Understanding and Promoting Human Care for Nature, Wiley. https://books.google.ca/books?id=61xxBgAAQBA]

Cooper, J. (2007). Cognitive Dissonance: 50 Years of a Classic Theory, SAGE Publications. http://books.google.com/books?id=yKi2cLshWiAC

Corbera, E., M. Estrada and K. Brown (2009). "How do regulated and voluntary carbon-offset schemes compare?" Journal of Integrative Environmental Sciences 6(I): 25-50. http://dx.doi.org/10.1080/15693430802703958

Daily, G. C., Ed. (1997). Nature's Services: Societal Dependence on Natural Ecosystems. Washington, DC, Island Press. http://www.amazon.ca/gp/product/I559634766/sr=II/qid = I I 55595726/ref=sr I I/702-8872424-790326 I ?ie=UTF8\&s=books 
Daily, G. C., P. M. Kareiva, S. Polasky, T. H. Ricketts and H. Tallis (20I I). Mainstreaming natural capital into decisions. Natural Capital: Theory \& Practice of Mapping Ecosystem Services. P. Kareiva, H. Tallis, T. H. Ricketts, G. C. Daily and S. Polasky. Oxford, UK, Oxford University Press: 3-I4. http://www.oup.com/us/catalog/general/subject/Economics/Policy/?view=usa\&sf=toc\&ci=9780199 588992

Daly, H. E. (2005). "Economics in a full world." Scientific American 293(3): 100-+. http://search.ebscohost.com/login.aspx?direct=true\&db=aph\&AN=| 7836492\&site=ehost-live

Dauvergne, P. and J. Lister (20/3). Eco-Business: A Big-Brand Takeover of Sustainability, MIT Press. http://books.google.ca/books?id=6PlalDcld38C

Dean Moore, K. and R. Russell (2009). Toward a new ethic for the oceans. Ecosystem-Based Management for the Oceans. K. McLeod and H. Leslie. Washington, D.C., Island Press: 324-340. http://books.google.com/books?id=yn4mL6u35tMC\&source=gbs_navlinks_s

Di Minin, E., N. Leader-Williams and C. J. A. Bradshaw (2016). "Banning trophy hunting will exacerbate biodiversity loss." Trends in Ecology \& Evolution 3I(2): 99-102. http://dx.doi.org/10.1016/j.tree.2015.12.006

Díaz, S., S. Demissew, C. Joly, et al. (2015). "The IPBES Conceptual Framework - connecting nature and people." Current Opinion in Environmental Sustainability I 4(June): I- 16. http://www.sciencedirect.com/science/article/pii/SI8773435I400II6X

Dirzo, R., H. S. Young, M. Galetti, G. Ceballos, N. J. B. Isaac and B. Collen (2014). "Defaunation in the Anthropocene." Science 345(6195): 40I-406. http://www.sciencemag.org/content/345/6195/401.abstract

Doak, D. F., V. J. Bakker, B. E. Goldstein and B. Hale (20I5). What is the future of conservation? Protecting the Wild. G. Wuerthner, E. Crist and T. Butler, Springer: 27-35.

Dobson, A. (2007). "Environmental citizenship: towards sustainable development." Sustainable Development 15(5): 276-285. http://dx.doi.org/10.1002/sd.344

Dowie, M. (2005). Conservation refugees. Orion Magazine. http://www.oriononline.org/pages/om/056om/Dowie.html

Economist, T. (2005). Are you being served? The Economist. 2005: 76-78.

Ehrlich, P. R. and R. M. Pringle (2008). "Where does biodiversity go from here? A grim business-as-usual forecast and a hopeful portfolio of partial solutions." Proceedings of the National Academy of Sciences 105(Supplement I): II579-I I586. http://www.pnas.org/content/ 105/suppl. I/I I579.abstract

Elster, J. (2000). Social norms and economic theory. Culture and Politics: A Reader. L. Crothers and C. Lockhart. New York, Palgrave Macmillan US: 363-380. http://dx.doi.org// 0.1007/978-I-34962397-6_20

Epstein, G., J. Pittman, S. M. Alexander, et al. (20I5). "Institutional fit and the sustainability of socialecological systems." Current Opinion in Environmental Sustainability I4: 34-40. http://dx.doi.org/10.1016/j.cosust.2015.03.005

Espinosa Romero, M. J. (2010). Towards ecosystem-based management: integrating stakeholder values in decision-making and improving the representation of ecosystems in ecosystem models. RMES. Vancouver, BC, University of British Columbia. M.Sc. http://hdl.handle.net/2429/28I 27

Fehr, E. and U. Fischbacher (2004). "Social norms and human cooperation." Trends in Cognitive Sciences 8(4): I85-1 90. http://www.sciencedirect.com/science/article/pii/SI 36466 I 304000506

Feldman, D. C. (1984). "The development and enforcement of group norms." Academy of Management Review 9(I): 47-53. http://amr.aom.org/content/9/1/47.abstract

Festinger, L. (1962). A Theory of Cognitive Dissonance, Stanford University Press. http://books.google.com/books?id=voeQ-8CASacC

Folke, C., T. Hahn, P. Olsson and J. Norberg (2005). "Adaptive governance of social-ecological systems." Annual Review of Environment and Resources 30(I): 44I-473. http://www.annualreviews.org/doi/abs/ I 0.I I 46/annurev.energy.30.050504.I445 I I 
Förster, J., J. Barkmann, R. Fricke, et al. (20I5). "Assessing ecosystem services for informing land-use decisions: a problem-oriented approach." Ecology and Society 20(3). http://www.ecologyandsociety.org/vol20/iss3/art3l/

Foster, J. B. (2002). Ecology Against Capitalism, Monthly Review Press. https://books.google.ca/books?id=rapGBAAAQBAJ

Fox, J., G. C. Daily, B. H. Thompson, K. M. A. Chan, A. Davis and A. Nino-Murcia (2006). Conservation Banking. The Endangered Species Act at Thirty: Conserving Biodiversity in the HumanDominated Landscape. J. M. Scott, D. D. Goble and F. W. Davis. Washington, DC, Island Press: 228-243.

Franco, J., N. Buxton, P. Vervest, T. Feodoroff, C. Pedersen, R. Reuter and M. C. Barbesgaard (20/4). The Global Ocean Grab: A Primer. Economic Justice Program, Transnational Institute. http://www.tni.org/briefing/global-ocean-grab-primer-0

Gifford, R. (20II). "The dragons of inaction: Psychological barriers that limit climate change mitigation and adaptation." American Psychologist 66(4): 290. http://www.scpknowledge.eu/sites/default/files/knowledge/attachments/The Dragons of Inaction.pdf

Goble, D. D., J. M. Scott and F. W. Davis (2005). The Endangered Species Act at Thirty: Vol. I : Renewing the Conservation Promise. Washington, DC, Island Press. https://books.google.ca/books?id=vEh7m I k5WMwC

Goldman, R. L., H. Tallis, P. Kareiva and G. C. Daily (2008). "Field evidence that ecosystem service projects support biodiversity and diversify options." Proceedings of the National Academy of Sciences of the United States of America 105(27): 9445-9448. http://dx.doi.org//0.1073/pnas.0800208/05

Goldman-Benner, R. L., S. Benitez, T. Boucher, A. Calvache, G. Daily, P. Kareiva, T. Kroeger and A. Ramos (20I2). "Water funds and payments for ecosystem services: practice learns from theory and theory can learn from practice." Oryx 46(0I): 55-63. http://dx.doi.org/10.1017/S0030605311001050

Gómez-Baggethun, E., R. de Groot, P. L. Lomas and C. Montes (20I0). "The history of ecosystem services in economic theory and practice: From early notions to markets and payment schemes." Ecological Economics 69(6): 1209-1218. http://www.sciencedirect.com/science/article/B6VDY-4XXM2HPI/2/262d5bd I 4da586b I4dfa2e2590ac30fd

Gómez-Baggethun, E. and M. Ruiz-Pérez (201 I). "Economic valuation and the commodification of ecosystem services." Progress in Physical Geography 35(5): 613-628. http://ppg.sagepub.com/content/35/5/613.abstract

Gould, R. K., S. C. Klain, N. M. Ardoin, T. Satterfield, U. Woodside, N. Hannahs, G. C. Daily and K. M. Chan (20I5). "A protocol for eliciting nonmaterial values using a cultural ecosystem services frame." Conservation Biology 29(2): 575-586. http://onlinelibrary.wiley.com/doi/I0.1 II I/cobi.12407/full

Gregory, R., L. Failing, M. Harstone, G. Long and T. McDaniels (20I2). Structured Decision Making: A Practical Guide to Environmental Management Choices. Hoboken, NJ, John Wiley \& Sons, Incorporated. http://books.google.ca/books?id=pU8-YgEACAAJ

Guerrero, A. M., Ö. Bodin, R. R. J. McAllister and K. A. Wilson (20I5). "Achieving social-ecological fit through bottom-up collaborative governance: an empirical investigation." Ecology and Society 20(4). http://www.ecologyandsociety.org/vol20/iss4/art4I/

Hare, R. M. (1991). Universal prescriptivism. A Companion to Ethics. P. Singer. Oxford, UK, Blackwell Publishers Inc: 45 I-463.

Heath, C. and D. Heath (20I0). Switch: How to Change Things When Change Is Hard. New York, Crown Publishing Group. http://books.google.ca/books?id=QgzBqhbdlvUC

Hechter, M. and K. D. Opp (200I). Social Norms, Russell Sage Foundation. https://books.google.ca/books?id=uPiFAwAAQBA] 
Hoffman, D. (2009). "Institutional legitimacy and co-management of a marine protected area: Implementation lessons from the case of Xcalak Reefs National Park, Mexico." Human Organization 68(I): 39-54. http://www.sfaajournals.net/doi/abs/I0.17730/humo.68.1.28gwl I06ul3II43h

Holzmann, R. and S. Jørgensen (200I). "Social risk management: A new conceptual framework for social protection, and beyond." International Tax and Public Finance 8(4): 529-556. http://dx.doi.org//0.1023/A:I0I I 247814590

Honey-Rosés, J. and L. H. Pendleton (2013). "A demand driven research agenda for ecosystem services." Ecosystem Services. http://dx.doi.org/10.1016/j.ecoser.2013.04.007

Igoe, J. (2004). "Disciplining democracy: Development discourses and good governance in Africa." The International journal of African historical studies 37(3): 577.

https://www.questia.com/library/journal/IP3-80634230I/disciplining-democracy-developmentdiscourses-and

Igoe, J., K. Neves and D. Brockington (2010). "A spectacular eco-tour around the historic bloc: Theorising the convergence of biodiversity conservation and capitalist expansion." Antipode 42(3): 486-5 I 2. http://dx.doi.org/I 0.1 I I I/j. I467-8330.2010.0076I.x

IPBES (Intergovernmental Science-Policy Platform on Biodiversity and Ecosystem Services) (20I5). Preliminary guide regarding diverse conceptualization of multiple values of nature and its benefits, including biodiversity and ecosystem functions and services (deliverable 3 (d)): 95. https://www.researchgate.net/publication/27/529734_Preliminary_guide_regarding_diverse_con ceptualization_of_multiple_values_of_nature_and_its_benefits_including_biodiversity_and_ecos ystem functions and services

Jack, B. K., C. Kousky and K. R. E. Sims (2008). "Designing payments for ecosystem services: Lessons from previous experience with incentive-based mechanisms." Proceedings of the National Academy of Sciences of the United States of America 105(28): 9465-9470. http://dx.doi.org// 0.1073/pnas.0705503/04

Jacobson, M. Z., M. A. Delucchi, G. Bazouin, et al. (20I5). "I00\% clean and renewable wind, water, and sunlight (WWS) all-sector energy roadmaps for the 50 United States." Energy \& Environmental Science 8(7): 2093-21 I7. http://dx.doi.org/10.1039/C5EE0 I283]

Jacquet, J., J. Hocevar, S. Lai, P. Majluf, N. Pelletier, T. Pitcher, E. Sala, R. Sumaila and D. Pauly (20I0a). "Conserving wild fish in a sea of market-based efforts." Oryx 44(I): 45-56. http://journals.cambridge.org/production/action/cjoGetFulltext?fulltextid=6829476

Jacquet, J., D. Pauly, D. Ainley, S. Holt, P. Dayton and J. Jackson (20I0b). "Seafood stewardship in crisis." Nature 467(73 I I): 28-29. http://dx.doi.org/l 0.1038/467028a

Jax, K., D. N. Barton, K. M. A. Chan, et al. (2013). "Ecosystem services and ethics." Ecological Economics 93(0): 260-268. http://www.sciencedirect.com/science/article/pii/S092 I8009/3002073

Jenks, B., P. W. Vaughan and P. J. Butler (2010). "The evolution of Rare Pride: Using evaluation to drive adaptive management in a biodiversity conservation organization." Evaluation and Program Planning 33(2): I86-190. http://www.sciencedirect.com/science/article/pii/S0 I 497/8909000755

Kahneman, D. (20I3). Thinking, Fast and Slow, Farrar, Straus and Giroux. http://books.google.ca/books?id=iBs9uAAACAA]

Kareiva, P. (20I4). "New conservation: Setting the record straight and finding common ground." Conservation Biology 28(3): 634-636. http://dx.doi.org//0.1 I I I/cobi. I 2295

Kareiva, P., R. Lalasz and M. Marvier (2012). "Conservation in the Anthropocene: beyond solitude and fragility." Breakthrough Journal(Winter). http://thebreakthrough.org/index.php/journal/pastissues/issue-2/conservation-in-the-anthropocene

Kinzig, A. P., C. Perrings, F. S. Chapin, S. Polasky, V. K. Smith, D. Tilman and B. L. Turner (20I I). "Paying for ecosystem services-Promise and peril." Science 334(6056): 603-604. http://www.sciencemag.org/content/334/6056/603.short 
Klain, S., T. Satterfield and K. M. A. Chan (20I4). "What matters and why? Ecosystem services and their bundled qualities." Ecological Economics 107: 310-320. http://www.sciencedirect.com/science/article/pii/S092/8009/4002730

Klain, S. C., K. M. A. Chan and T. Satterfield (in prep.). "Quantifying public support for ecologically regenerative renewable energy: High willingness to pay for offshore wind farms with biodiversity benefits."

Kosoy, N. and E. Corbera (2010). "Payments for ecosystem services as commodity fetishism." Ecological Economics 69(6): 1228-1236. http://www.sciencedirect.com/science/article/pii/S092I8009090045I0

Lapinski, M. K. and R. N. Rimal (2005). "An explication of social norms." Communication Theory I5(2): I27-I47. http://dx.doi.org/I 0.I I I I/j.I 468-2885.2005.tb00329.x

Laurans, Y., A. Rankovic, R. Billé, R. Pirard and L. Mermet (2013). "Use of ecosystem services economic valuation for decision making: Questioning a literature blindspot." Journal of Environmental Management I I9: 208-219. http://www.sciencedirect.com/science/article/pii/S030 I4797/3000285

Levin, S. A. (1996). "Economic growth and environmental quality." Ecological Applications 6(I): I2-I2. http://www.jstor.org/stable/2269538

Lockwood, M., J. Davidson, A. Curtis, E. Stratford and R. Griffith (2010). "Governance principles for natural resource management." Society \& Natural Resources 23(10): 986-100I. http://dx.doi.org//0.1080/089419208021782/4

Louv, R. (2008). Last Child in the Woods: Saving Our Children from Nature-Deficit Disorder. Chapel Hill, NC, Algonquin Books. http://richardlouv.com/last-child-purchase

Luck, G., K. M. A. Chan, U. Eser, E. Gómez-Baggethun, B. Matzdorf, B. Norton and M. Potschin (20I2). "Ethical considerations in on-ground applications of the ecosystem services concept." BioScience 62(12): 1020-1029. http://dx.doi.org/10.1525/bio.2012.62.12.4

Luck, G. W., K. M. A. Chan and J. P. Fay (2009). "Protecting ecosystem services and biodiversity in the world's watersheds." Conservation Letters 2: 179- I88. http://dx.doi.org//0.1 I I //j.1755263X.2009.00064.x

Marris, E. (20II). Rambunctious Garden: Saving Nature in a Post-Wild World, Bloomsbury Publishing. http://books.google.ca/books?id=vW bWhe5rwIC

Marris, E. (20I4). "'New conservation' is an expansion of approaches, not an ethical orientation." Animal Conservation: n/a-n/a. http://dx.doi.org/l0.1III/acv.12129

Martín-López, B., I. Iniesta-Arandia, M. García-Llorente, et al. (20I2). "Uncovering ecosystem service bundles through social preferences." PLoS ONE 7(6): e38970. http://dx.doi.org//0.1371\%2Fjournal.pone.0038970

Martinez-Alier, J. (2002). The Environmentalism of the Poor: A Study of Ecological Conflicts and Valuation. Northampton, MA, Edward Elgar Pub. http://books.google.com/books?id=JR7_onvkj8UC\&source=gbs navlinks s

Martinez-Harms, M. J., B. A. Bryan, P. Balvanera, E. A. Law, J. R. Rhodes, H. P. Possingham and K. A. Wilson (2015). "Making decisions for managing ecosystem services." Biological Conservation 184: 229-238. http://www.sciencedirect.com/science/article/pii/S00063207/5000452

Marvier, M. and H. Wong (20I2). "Resurrecting the conservation movement." Journal of Environmental Studies and Sciences 2(4): 29I-295. http://dx.doi.org/I0.1007/s |34/2-012-0096-6

McCauley, D. J. (2006). "Selling out on nature." Nature 443(7/ 07): 27-28. http://www.nature.com/nature/journal/v443/n7/07/pdf/443027a.pdf

McClenachan, L., B. P. Neal, D. Al-Abdulrazzak, T. Witkin, K. Fisher and J. N. Kittinger (2014). "Do community supported fisheries (CSFs) improve sustainability?" Fisheries Research 157: 62-69. http://www.sciencedirect.com/science/article/pii/SOI657836/4000988 
McLain, R. J., P. T. Hurley, M. R. Emery and M. R. Poe (2014). "Gathering "wild" food in the city: rethinking the role of foraging in urban ecosystem planning and management." Local Environment 19(2): 220-240. http://dx.doi.org//0.1080/I3549839.2013.84I659

Millennium Ecosystem Assessment (2005). Ecosystems and Human Well-being: Synthesis. Washington, DC, Island Press. http://www.millenniumassessment.org/documents/document.356.aspx.pdf

Miller, K., J. Trezise, S. Kraus, K. Dripps, M. Evans, P. Gibbons, H. P. Possingham and M. Maron (20I5). "The development of the Australian environmental offsets policy: from theory to practice." Environmental Conservation FirstView: I-9. http://dx.doi.org/10.1017/S03768929/400040X

Minson, J. A. and B. Monin (20I2). "Do-gooder derogation: Disparaging morally motivated minorities to defuse anticipated reproach." Social Psychological and Personality Science 3(2): 200-207. http://spp.sagepub.com/content/3/2/200.abstract

Moreno-Mateos, D., V. Maris, A. Béchet and M. Curran (2015). "The true loss caused by biodiversity offsets." Biological Conservation 192: 552-559. http://www.sciencedirect.com/science/article/pii/S00063207/5300665

Muradian, R., M. Arsel, L. Pellegrini, et al. (2013). "Payments for ecosystem services and the fatal attraction of win-win solutions." Conservation Letters 6(4): 274-279. http://dx.doi.org//0.1III/j.1755-263X.2012.00309.x

Naeem, S., J. C. Ingram, A. Varga, et al. (2015). "Get the science right when paying for nature's services." Science 347(6227): I 206-1 207. http://www.sciencemag.org/content/347/6227//206.short

Naidoo, R., A. Balmford, R. Costanza, B. Fisher, R. E. Green, B. Lehner, T. R. Malcolm and T. H. Ricketts (2008). "Global mapping of ecosystem services and conservation priorities." Proceedings of the National Academy of Sciences 105(28): 9495-9500. http://www.pnas.org/content//05/28/9495.abstract

Naidoo, R. and T. H. Ricketts (2006). "Mapping the economic costs and benefits of conservation." PLoS Biology 4(II): 2153-2164. http://biology.plosjournals.org/perlserv/?request=getdocument\&doi=10.1371\%2Fjournal.pbio.0040360

Norgaard, R. B. (2010). "Ecosystem services: From eye-opening metaphor to complexity blinder." Ecological Economics 69(6): 1219-1227. http://dx.doi.org/10.1016/j.ecolecon.2009.11.009

Norton, B. G. and B. Hannon (1997). "Environmental values: A place-based theory." Environmental Ethics 19(3): 227-245. http://dx.doi.org/I0.5840/enviroethics /997/93 I3

Norton, B. G. and D. Noonan (2007). "Ecology and valuation: Big changes needed." Ecological Economics 63(4): 664-675. http://dx.doi.org/I0.1016/j.ecolecon.2007.02.013

Olmsted, P. (20I6). Social Impact Investing and the Changing Face of Conservation Finance, IUCN: 32. https://www.iucn.org/sites/dev/files/pdf_final_social_impact_investing.pdf

Olmsted, P. and K. M. A. Chan (in prep.). "Conservation stewardship and social impact investing."

Onwezen, M. C., G. Antonides and J. Bartels (2013). "The Norm Activation Model: An exploration of the functions of anticipated pride and guilt in pro-environmental behaviour." Journal of Economic Psychology 39: I4I-I 53. http://www.sciencedirect.com/science/article/pii/S0 I674870 I 3000950

Ostrom, E., M. A. Janssen and J. M. Anderies (2007). "Going beyond panaceas." Proceedings of the National Academy of Sciences of the United States of America 104: 15176-15178. http://www.pnas.org/content//04/39/15176

Pascual, U., J. Phelps, E. Garmendia, K. Brown, E. Corbera, A. Martin, E. Gomez-Baggethun and R. Muradian (2014). "Social equity matters in payments for ecosystem services." BioScience 64(I I): 1027-I036. http://bioscience.oxfordjournals.org/content/64// I// 027.abstract

Peterson, M. J., D. M. Hall, A. M. Feldpausch-Parker and T. R. Peterson (2010). "Obscuring ecosystem function with application of the ecosystem services concept." Conservation Biology 24(I): II3119. http://dx.doi.org/10.1III/j.1523-1739.2009.01305.x

Plieninger, T., C. Bieling, B. Ohnesorge, H. Schaich, C. Schleyer and F. Wolff (2013). "Exploring futures of ecosystem services in cultural landscapes through participatory scenario development in the 
Swabian Alb, Germany." Ecology and Society 18(3).

http://www.ecologyandsociety.org/voll 8/iss3/art39/

Poe, M. R., J. Donatuto and T. Satterfield (2016). "“Sense of place": Human wellbeing considerations for ecological restoration in Puget Sound." Coastal Management: I- I8. http://dx.doi.org// 0.1080/08920753.2016.1208037

Poe, M. R., J. LeCompte, R. McLain and P. Hurley (2014). "Urban foraging and the relational ecologies of belonging." Social \& Cultural Geography I 5(8): 901-919. http://dx.doi.org//0.1080//4649365.2014.908232

Polasky, S., H. Doremus and B. Rettig (1997). "Endangered species conservation on private land." Contemporary Economic Policy I 5(4): 66-76. http://onlinelibrary.wiley.com/doi//0.1 I I //j. I4657287.1997.tb00490.x/abstract

Rawls, J. (197I). A Theory of Justice. Cambridge, MA, The Belknap Press of Harvard University Press.

Rees, W. E. (1998). "How should a parasite value its host?" Ecological Economics 25(I): 49-52. http://dx.doi.org/10.1016/S0921-8009(98)00015-9

Reno, R. R., R. B. Cialdini and C. A. Kallgren (1993). "The transsituational influence of social norms." Journal of personality and social psychology 64(I): 104. https://www.researchgate.net/profile/Robert_Cialdini/publication/232604958_The transsituation al_influence_of_social_norms/links/0a85e53b2ea8bel795000000.pdf

Ruckelshaus, M., E. McKenzie, H. Tallis, et al. (20I5). "Notes from the field: Lessons learned from using ecosystem service approaches to inform real-world decisions." Ecological Economics II 5: II2I. http://www.sciencedirect.com/science/article/pii/S09218009/3002498

Scannell, L. and R. Gifford (2010a). "Defining place attachment: A tripartite organizing framework." Journal of Environmental Psychology 30(I): I-I0. http://www.sciencedirect.com/science/article/pii/S0272494409000620

Scannell, L. and R. Gifford (20I0b). "The relations between natural and civic place attachment and proenvironmental behavior." Journal of Environmental Psychology 30(3): 289-297. http://www.sciencedirect.com/science/article/pii/S02724944I0000198

Schlosberg, D. (2004). "Reconceiving environmental justice: Global movements and political theories." Environmental Politics I3(3): 5 I 7-540.

Schomers, S. and B. Matzdorf (2013). "Payments for ecosystem services: A review and comparison of developing and industrialized countries." Ecosystem Services 6(0): 16-30. http://www.sciencedirect.com/science/article/pii/S22I204I6I300003X

Scott, J. M., D. D. Goble and F. W. Davis (2006). The Endangered Species Act at Thirty: Vol. 2 : Conserving Biodiversity in Human-Dominated Landscapes. Washington, DC, Island Press. https://books.google.ca/books?id=lujtr72vqi0C

Shellenberger, M. and T. Nordhaus (2004). The Death of Environmentalism: Global Warming Politics in a Post-Environmental World. http://www.thebreakthrough.org

Shove, E. (20I0). "Beyond the ABC: climate change policy and theories of social change." Environment and Planning A 42(6): I 273- I 285. https://blog.itu.dk/hest/files/2012/10/shove abc.pdf

Sikor, T. (20/3). The Justices and Injustices of Ecosystem Services. New York, NY, Taylor \& Francis. http://books.google.ca/books?id=dd0cAAAAQBA]

Smith, R. J., D. Verissimo, N. Leader-Williams, R. M. Cowling and A. T. Knight (2009). "Let the locals lead." Nature 462(727I): 280-28I. http://dx.doi.org/l0.1038/462280a

Soulé, M. (2013). "The "new conservation"." Conservation Biology 27(5): 895-897. http://dx.doi.org/I0.1III/cobi.I2I47

Steffen, W., P. J. Crutzen and J. R. McNeill (2007). "The Anthropocene: are humans now overwhelming the great forces of nature." AMBIO: A Journal of the Human Environment 36(8): 6I4-62I. http://dx.doi.org//0.1579/0044-7447(2007)36\%5B6/4:TAAHNO\%5D2.0.CO;2

Tallis, H., C. M. Kennedy, M. Ruckelshaus, J. Goldstein and J. M. Kiesecker (2015). "Mitigation for one \& all: An integrated framework for mitigation of development impacts on biodiversity and 
ecosystem services." Environmental Impact Assessment Review 55(0): 21-34. http://www.sciencedirect.com/science/article/pii/SOI 959255 I5000566

TEEB - The Economics of Ecosystems and Biodiversity for National and International Policy Makers (2009). Wesseling, Germany, United Nations Environment Programme. http://www.teebweb.org/ForPolicymakers/tabid/I019/language/en-US/Default.aspx

Thaler, R. H. and C. R. Sunstein (2008). Nudge: Improving Decisions about Health, Wealth, and Happiness, Yale University Press. http://books.google.ca/books?id=dSJQn8egXvUC

Turner, R. A., C. Fitzsimmons, J. Forster, R. Mahon, A. Peterson and S. M. Stead (20I4). "Measuring good governance for complex ecosystems: Perceptions of coral reef-dependent communities in the Caribbean." Global Environmental Change 29: 105-I 17. http://www.sciencedirect.com/science/article/pii/S09593780I400I447

Turner, W. R., K. Brandon, T. M. Brooks, R. Costanza, G. A. B. da Fonseca and R. Portela (2007). "Global conservation of biodiversity and ecosystem services." Bioscience 57(I0): 868-873. http://dx.doi.org/10.164I/B57/009

Vatn, A. (2010). "An institutional analysis of payments for environmental services." Ecological Economics 69(6): I245-1252. http://www.sciencedirect.com/science/article/pii/S092 I800909004674

Veríssimo, D. (20/3). "Influencing human behaviour: an underutilised tool for biodiversity management." Conservation Evidence 10: 29-31.

Vira, B. and W. M. Adams (2009). "Ecosystem services and conservation strategy: beware the silver bullet." Conservation Letters 2(4): I58-162. http://dx.doi.org/I0.1 I I /j. I755-263X.2009.00063.x

Warner, M. E. (2013). "Private finance for public goods: social impact bonds." Journal of Economic Policy Reform 16(4): 303-319. http://dx.doi.org/10.1080/17487870.2013.835727

West, P. and D. Brockington (2006). "An anthropological perspective on some unexpected consequences of protected areas." Conservation Biology 20(3): 609-616. http://www.blackwellsynergy.com/doi/abs/I0.1III/j.1523-1739.2006.00432.x

Wilcove, D. S. and J. Lee (2004). "Using economic and regulatory incentives to restore endangered species: Lessons learned from three new programs." Conservation Biology 18(3): 639-645. http://www.blackwell-synergy.com/doi/abs/I0.IIII/j.I523-I739.2004.00250.x

Wittman, H., L. J. Powell and E. Corbera (20I5). "Financing the agrarian transition? The Clean Development Mechanism and agricultural change in Latin America." Environment and Planning A 47(10): 203 I-2046. http://epn.sagepub.com/content/47//0/203I.abstract

Wittman, H. K. and C. Caron (2009). "Carbon offsets and inequality: Social costs and co-benefits in Guatemala and Sri Lanka." Society \& Natural Resources 22(8): 710-726. http://dx.doi.org// 0.1080/0894/920802046858

World Resources Institute (WRI), World Business Council on Sustainable Development (WBCSD) and Meridian Institute (2008). The Corporate Ecosystem Services Review: Guidelines for Identifying Business Risks and Opportunities Arising from Ecosystem Change. WBCSD Publications: 37+vi. http://www.wbcsd.org/Plugins/DocSearch/details.asp?DocTypeld=25\&Objectld=Mjg5NjQ

Wright, A. J., D. Veríssimo, K. Pilfold, et al. (20I5). "Competitive outreach in the 2 I st century: Why we need conservation marketing." Ocean \& Coastal Management I I 5: 4I-48. http://www.sciencedirect.com/science/article/pii/S0964569II500I829

Wunder, S. (2006). "Are direct payments for environmental services spelling doom for sustainable forest management in the tropics?" Ecology and Society I I (2). http://www.ecologyandsociety.org/voll I/iss2/art23/

Wunder, S. (20I3). "When payments for environmental services will work for conservation." Conservation Letters 6(4): 230-237. http://dx.doi.org/I0.1 I II/conl.I2034

Young, O. R. (2002). The Institutional Dimensions of Environmental Change: Fit, Interplay, and Scale. Cambridge, MA, MIT Press. https://books.google.ca/books?id=jd8rD4gEJLQC 